To the paper

\title{
Errata
}

\section{STUDIES ON THE SOLUBILITY OF Pu(III) OXALATE}

S. P. HASILKAR, N. B. KHEDEKAR, KESHAV CHANDER, A. V. JADHAV, H. C. JAIN

Fuel Chemistry Division, Bhabha Atomic Research Centre,, Trombay, Bombay 400085 (India)

appeared in

Journal of Radioanalytical and Nuclear Chemistry, Articles, Vol. 185, No. 1(I994) 119-125.

On page 119 in rows 26 and 27 :

...oxalate in $\mathrm{HCl}$ and $\mathrm{HNO}_{3}$ media...

instead of

...oxalate in $\mathrm{HCl}$ oxalate in $\mathrm{HCl}$ and $\mathrm{HNO}_{3}$ media...

On page 120 in row 5 :

...plutonium the desired...

instead of

...plutonium at the desired...

in row 30:

...at 565 and $603 \mathrm{~nm}$ in time...

instead of

...at 565 and $603 \mathrm{~nm}$ with time...

On page 124 in row 8 from the bottom:

...in to $\mathrm{Pu} \mathrm{O}_{2}$ by...

instead of

...in to $\mathrm{Pu}_{2} \mathrm{O}_{2}$ by ... 